\title{
When All She Intended Was Blue Sky
}

\author{
Margaret Webb
}

\begin{abstract}
Quand toute son intention n'était que du ciel bleu
Après avoir vu une mise en scène de désir lesbien au théâtre - désir point considéré lesbien puisque les acteurs sont en train de mourir - le "je" du poème se rappelle embrasser une fille sur la banquette arrière de la voiture de son père - scène également "non lesbienne" puisque les deux filles simulaient une étreinte hétérosexuelle. Toutefois, une fois provoquée, la mémoire de la fille sur la banquette arrière de la voiture refait surface, interrompant le récit apparamment stable de la vie de la narratrice avec son mari. Webb assimile le lesbianismeà une partie manquant au discours dominant - comme des répliques oubliées d'un rôle - dans lequel les femmes déclarent leur "véritable" désir l'une pour l'autre. Comment récupérer cette partie de texte du domaine du prétendu? Comment utiliser l'imaginaire, non seulement pour perturber le "réel," mais pour devenir "réel"? Comment empêcher la narration de se refermer sur ce texte manquant, pour projeter la mémoire de façon à ce qu'un futur différent soit joué? Dans ce texte, ce dont "elle" se rend compte c'est ce que "tu" a toujours su-que "je" n'a fait que prétendre toute sa vie.
\end{abstract}

13 and I am

kissing a girl in the backseat of my father's car

either I am pretending she is a guy or I am a guy

either way

it's not lesbian

because of the pretending 
the first time I met him I seduced him

or at least if we looked back and had to say

who seduced whom

we would have to say it was me because I kissed him first and then he kissed me

and then we were just tongues inside each other's mouths

he being an Arab Jew

is what I like about him

that he doesn't fit inside

any borders

he has parties

inviting his Jewish friends and his Arab friends and I end up fighting with them in the kitchen about which part of him they don't like

defending the other part at the same time not liking the part of him I am fighting with at that moment

we argue like this for hours not giving a single thought to how many fights like this occur in kitchens

after she gets to know him

the she being me 
I am talking

in the third person because it seems more appropriate

at this moment

the girl from the back seat showing up in my life at the oddest of moments

I have been turned down for a part in a play but I have the lines so I say them anyway

and she is the only person in the audience

or a lump has been removed from my breast

I am lying in a hospital bed and she is lying beside me

she has also had a lump removed from her breast

the doctor says our lumps are benign

but they are missing to us anyway

$$
\text { * }
$$

standing in a bookstore on Sunday afternoon she pulls down every new release of poetry

and realizes she hates poetry

after writing poetry for twenty years suddenly every bright flip of metaphor grates on her nerves like sunshine outside when she's inside writing

wanting to be outside 
drinking wine at the cafe across the street

a glass of white wine

a cool glass of dry white wine

when you realize there is a rhythm in poetry

stress, repetition, cadence

careful-

ly measured out so you can't break out

you can argue about it in the kitchen

strain against it even as it inserts

a child into your life

a house with a backyard

when all you intended was blue sky

another time the girl from the back seat and I are sitting with a group of girls under a tree in a meadow

we are older so the thickening of skin on our chests is thicker

and some of us are pretending to be guys and the rest of us are pretending to be girls 
either way

because of the pretending

it's not lesbian

after this she grew up

after this she fell in love with her Arab-Jewish boyfriend and got married after this she started running into the girl from the back seat of the car at the oddest of moments

sometimes she can't stop

writing about herself

in the third person

she thinks if she were the writer of the poetry she is reading she could simply stop writing and go to the cafe across the street for a glass of wine no one should have to tell someone else how good and cool a glass of wine would taste

if she writes about herself in the second person she would have to tell herself things she does not want to hear 
when you make love with your husband you fantasize that you are with the girl from the backseat of the car

you being second person plural

so there is no question that you are making love

and not masturbating

you go to a play with your husband and discover it was written by the girl from the back seat of the car

the girl being a woman now

the play having occured before the lumps were removed from your breasts

the you being second-person plural

in the play two women are lying in bed dying and the doctor says they are dying so the audience knows they are dying and your husband leans over and whispers, "Christ, they are dying"

even though the two women are in bed, lying together, clinging together there is no question the scene is not lesbian

because of the dying

*

it is a play in which the actors forget one or two of the lines

after the author says, "whole chunks of text went missing" 
but the play closes in around the space and the audience does not notice the space

after a while the author doesn't notice either

even without constructing a story this is what happens

$*$

after I decide that I hate poetry I find myself in the kitchen at a party talking to someone who says poetry is like wallpaper

I spend the whole party in the kitchen arguing the merits of poetry arguing with him even as he is leaving

all the way down the hallway and into the elevator

until I can see he is afraid that I will follow him home

$*$

you have to be pulled out of the elevator by your Arab-Jewish husband who wants to be friends with everyone

I am not able to dissect which part of me is Arab and which part is Jewish

my psychiatrist says that my being Canadian and WASP makes it an interesting theoretical question, but how could you know anyway? 
after the play I have a reunion with the playwright who used to be the girl from the back seat of the car

we hug to say hello then we hug to say goodbye

in between we get each other glasses of wine because it is opening night and there is free wine

after that we walk each other to the door because the reception is over

and in the space she says

I have always been attracted to you

and I say

I have always been attracted to you

and then we say goodbye because the reception is over

the front door of the theatre closing over these two lines of text

$$
*
$$

being in the second-person makes you wonder

why did the author simply not create a character who would run back into the theatre and retrieve those two lines of text?

if you went running back and she wasn't there

where would the story be then

her Arab-Jewish husband touches her arm and opens the door of the taxi 
moments before he had raised his arm and hailed the taxi she wonders how many times he has come running after her how certain he must be of her reality

she has walked past the theatre many times since and it has always been there considering the reality of the poem, it becomes impossible to analyze the Arab-Jewishness of her husband the girl from the back seat of a car a woman named by pronouns you wonder if what will appear is a house with a backyard when all she intended was blue sky

you wonder if she can go back to that moment with the girl in the back seat of the car

without pretending

this time

you wonder if her life is pretending now and if that pretending then was the only thing real 


$$
\text { 80. Tessera }
$$

the present having closed over the past where she was not acting but pretending

the past acting to become present acting to become future you could pretend that none of this is happening to you

\section{*}

in the bookstore you turn the page of the book you are reading when you come to the very last word on the page

I wasn't conscious at all of speaking missing lines

we had been practising all our lives

to say this

and to say this

sitting in the cafe

drinking a glass of wine

the taste of letting go, into

*

the strain of holding the girl from the back seat of the car

all my life

at a distance

making my life in that distance 
if you finish the poem you could make the girl from the back seat of the car and the woman in the bookstore meet

in a theatre, a poem, a cafe

when we stand outside theatres

my Arab-Jewish husband orders us taxis and taxis continue to respond so that I can hardly doubt our reality here

the comfortable parts of our lives filling in like props

to make props lie flat on the stage you must cut off their ragged bottoms who is he ordering taxis for

when I imagine a life with this girl from the back seat of the car shopping lists are left on scraps of paper on the fridge door which seems more real than the note I leave her after the first night we spend together:

I slept with

slept with a woman

a woman I love

her breast

warm

in my mouth

girl

girl 


\section{Tessera}

and after

the way the morning sun makes a pattern on the floor

I'm not sure how she'll read it

whether she'll interpret it as a sign to bring groceries back from the store or whether I'll be there when she gets back

whether she is

or I am

and this is

tentative

I imagine

we will start leaving notes like this 